\title{
Efektifitas Cuka Kayu sebagai Pestisida Nabati dalam Pengendalian Hama Crocidolomia Pavonana dan Zat Perangsang Tumbuh pada Sawi
}

\section{Effectiveness of Wood Vinegar As Botanical Pesticides in Pest Control of Crocidolomia Pavonana and Growth Stimulating Substances on Mustard}

\author{
Nunung Ambarwati ${ }^{1}$, Subagiya ${ }^{2)}$, YV Pardjo NS ${ }^{2)}$
}

\begin{abstract}
Cabbage caterpillar pests (Crocidolomia pavonana) is one of the main obstacles inhibiting the production both in quality and quantity. Control is generally done with chemical pesticides that can harm the environment and humans. Wood vinegar is an agricultural waste that is used to increase the quantity and quality of mustard plant. This study aims to determine the effectiveness of wood vinegar as a botanical pesticide in the mustard plant and the PGR and the most effective concentration. Research using completely randomized design with 7 degree treatment laboratory tests (mortality, biology, kemampua eating) and 8 standard treatment field test (the intensity of pest attack, plant height, leaf number and weight of mustard plant), repeated 3 times. The results showed that wood vinegar is not effective as a pesticide plant pest control C.pavonana the mustard. Wood vinegar speed up the life cycle C. pavonana. Wood Vinegar can help to enhance and augment leaf mustard plant so that it can be effective as an aphrodisiac mustard plant grows. The greater the concentration of a given wood vinegar, increased growth (both height and number of leaves of mustard plant).
\end{abstract}

Keywords : wood vinegar, Crocidolomia pavonana, mustard, botanical pesticides, ZPT

\section{PENDAHULUAN}

Sawi merupakan jenis sayuran yang banyak digemari oleh para konsumen di berbagai lapisan masyarakat. Biasanya masyarakat memanfaatkan seluruh bagian tanaman sawi untuk dimakan, kecuali akar. Hal tersebut membuka peluang yang besar untuk pasar jenis sayuran sawi. Dalam pembudidayaan tanaman sawi, salah satu kendala utama yang menjadi penghambat produksi baik secara kualitas maupun kuantitas, adalah adanya serangan organisme pengganggu tanaman

(Anonim 2003).

Permasalahan hama pada tanaman sawi sampai saat ini masih merupakan faktor utama yang menghambat produksi, karena serangan hama dapat menurunkan hasil sampai $100 \%$. Diantara hama yang menyerang sawi adalah Crocidolomia pavonana dan Plutella xylostella L. Dua jenis hama tersebut sering kali bergantian menempati kedudukan sebagai hama utama (Sudarwohadi dan Wiwin 1993).

Pada umumnya, petani melakukan pengendalian dengan menggunakan pestisida sintetik (kimia) yang sangat membahayakan bagi lingkungan dan manusia itu sendiri. Oleh karena itu, digunakan cuka kayu yang merupakan limbah pertanian untuk mengatasi masalah tersebut guna meningkatkan kuantitas mupun kualitas tanaman sawi. Cuka kayu bisa menjadi bahan obat- obatan (industri farmasi), kosmetika dan zat perangsang tumbuhan (ZPT)

\footnotetext{
1) Undergraduate Student of Study Program of Agrotechnology, Faculty of Agriculture, the Universitas Sebelas Maret (UNS) in Surakarta.

${ }^{2)}$ Lecturer of Study Program of Agrotechnology, Faculty of Agriculture, the Universitas Sebelas Maret (UNS) in Surakarta.
}

Contact Author: subagiya_agt@uns.ac.id
(Anonim 2012). Balfas $R$ dan Sutopo (1998) juga berhasil membuktikan manfaat destilat (asam cuka kayu) ini pada ulat pemakan daun wungu dan kumbang moncong lada. Penelitian ini bertujuan untuk mengetahui efektifitas cuka kayu sebagai pestisida nabati dan zat perangsang tumbuh pada tanaman sawi serta konsentrasinya yang paling efektif.

\section{METODE PENELITIAN}

Penelitian ini telah dilaksanakan di Laboratorium Hama Penyakit Tanaman Fakltas Pertanian UNS dan di Desa Wates Panekan Magetan mulai bulan April Agustus 2012. Bahan yang digunakan ialah cuka kayu, larva C. pavonana, benih tanaman sawi, tanah, kompos, pupuk NPK, cairan madu dan air. Alat yang digunakan adalah kotak pemeliharaan larva berukuran $10 \times 10 \times 5 \mathrm{~cm}^{3}$, kotak pemeliharaan imago berukuran $15 \times 10 \times 10 \mathrm{~cm}^{3}$, toples ukuran $14 \times 14 \times 16$, hand sprayer sebagai alat penyemprot, paranet, penggaris, tali plastik, alat tulis, polibag, kertas tissue, kapas, gembor, kamera digital, timbangan, kain saring, bambu, dan alat-alat pendukung lainnya.

Penelitian ini menggunakan metode eksperimental dengan penentuan satuan unit sampel adalah satu $C$. pavonana dan satu tanaman sawi. Percobaan disusun menggunakan Rancangan Acak Lengkap (RAL) pada keadaan lingkungan yang seragam. Analisis data hasil pengamatan pada variabel respon pengamatan menggunakan analisis ragam berdasarkan uji $\mathrm{F}$ taraf $5 \%$ dan jika terdapat beda nyata dilanjutkan dengan uji DMRT (Duncan Multiple Range Test) taraf 5\%.

Penelitian dilakukan dengan melakukan penelitian pendahuluan di laboratorium untuk mengetahui mortalitas dan kemampuan makan. Selanjutnya dilakukan uji efektifitas untuk mengetahui biologi, kemampuan makan, intensitas serangan hama, tinggi 
tanaman, jumlah daun, dan berat brangkasan sawi. Intensitas serangan hama dapat dihitung dengan melakukan skoring pada daun yang terserang.

\section{HASIL DAN PEMBAHASAN}

\section{Uji Pendahuluan}

\section{Pengaruh Cuka Kayu terhadap Mortalitas $C$. pavonana}

Hasil penelitian menunjukkan bahwa pengaplikasian cuka kayu terhadap Crocidolomia pavonana dengan berbagai taraf perlakuan tidak mengalami kematian. Tidak ada satupun yang menunjukkan tanda- tanda gejala kematian. Dari data yang didapat, aplikasi penyemprotan cuka kayu pada daun sawi tidak menyebabkan kematian pada $C$. pavonana tetapi menyebabkan daun sawi menjadi lebih segar dan bisa bertahan lebih lama. Hal ini disebabkan karena adanya kandungan fenol yang mampu mengawetkan kesegaran daun tanaman sawi. Senyawa-senyawa fenol merupakan senyawa yang berperan sebagai antioksidan sehingga dapat memperpanjang masa simpan produk asapan (Girard 1992). Daun sawi yang lebih segar mengakibatkan larva menjadi cepat besar karena teredianya makanan yang memadai, sehingga pembentukan ke stadia pupa lebih cepat. Jadi, aplikasi cuka kayu tidak berdampak pada kematian tetapi berdampak pada biologi C. pavonana.
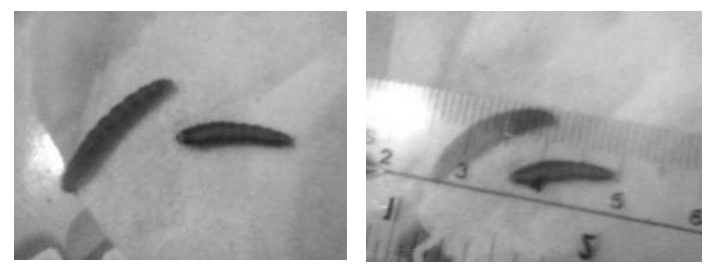

Gambar 1. Perbedaan larva aplikasi cuka kayu dengan yang normal

\section{Pengaruh Cuka Kayu terhadap Kemampuan Makan C. pavonana}

Pada penelitian ini, kemampuan makan $C$. pavonana didahului dengan melakukan pengamatan pendahuluan dengan perbandingan antara perlakuan aplikasi cuka kayu $20 \mathrm{ml} \mathrm{I}^{-1}$ dan tanpa perlakuan cuka kayu yang diletakkan pada satu wadah dengan jarak antara larva dengan kedua daun sama. Dari penelitian pendahuluan tersebut dapat dilihat larva $C$. pavonana lebih memilih daun perlakuan aplikasi cuka kayu atau tanpa perlakuan cuka kayu.

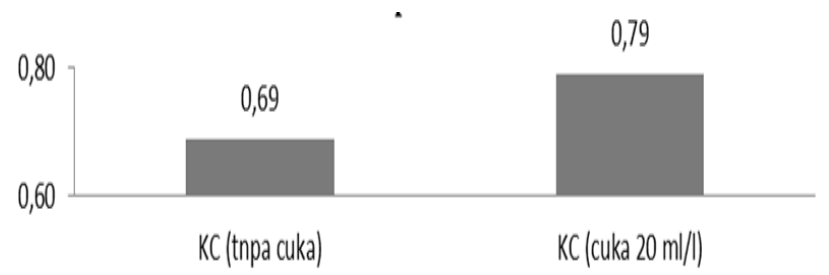

Gambar 2. Perbandingan kemampuan makan antara perlakuan cuka kayu dan perlakuan tanpa cuka kayu

\section{Uji Efektifitas}

\section{Efektifitas Cuka Kayu terhadap Biologi $C$. pavonana}

Sudarmono dan Subiyakto (1991) melakukan penelitian dan membuktikan bahwa ulat mengalami empat instar, lama hidup 14 hari. Perlakuan dengan berbagai konsentrasi cuka kayu menunjukkan lama stadia larva rata- rata sekitar 12 hari, hanya konsentrasi cuka kayu $20 \mathrm{ml} / \mathrm{l}$ yang menunjukkan lama stadia larva 13 hari.

Tabel 1. Pengaruh aplikasi cuka kayu terhadap biologi C. pavonana

\begin{tabular}{lcccc} 
& \multicolumn{4}{c}{ Variabel (hari) } \\
\cline { 2 - 5 } Pengamatan & $\begin{array}{l}\text { Lama } \\
\text { Stadia } \\
\text { Larva }\end{array}$ & $\begin{array}{c}\text { Lama } \\
\text { Stadia } \\
\text { Pupa }\end{array}$ & $\begin{array}{c}\text { Lama } \\
\text { Stadia } \\
\text { Imago }\end{array}$ & $\begin{array}{c}\text { Lama } \\
\text { Total }\end{array}$ \\
\hline $\begin{array}{l}\text { Kontrol (K0) } \\
\text { Konsentrasi } \\
\mathrm{ml} \mathrm{I}^{-1} \text { (K1) }\end{array}$ & 14 & 9 & 9 & 32 \\
$\mathrm{Konsentrasi}^{-1}$ & 12 & 8 & 12 & 32 \\
$10 \mathrm{ml} \mathrm{I}^{-1}$ (K2) & 12 & 9 & 14 & 35 \\
$\begin{array}{l}\text { Konsentrasi } \\
20 \mathrm{ml} \mathrm{I}^{-1} \text { (K3) }\end{array}$ & 13 & 8 & 12 & 33 \\
$\begin{array}{l}\text { Konsentrasi } \\
40 \mathrm{ml} \mathrm{I}^{-1} \text { (K4) } \\
\text { Konsentrasi } \\
80 \mathrm{ml} \mathrm{I}^{-1} \text { (K5) }\end{array}$ & 12 & 8 & 13 & 33 \\
\hline
\end{tabular}

Pupa berada di dalam tanah, masa pupa sekitar sembilan hari (Sudarmono dan Subiyakto 1991). Pada tabel 1, hasil pengamatan menunjukkan lama stadia pupa kontrol yaitu sembilan hari. Kondisi yang sama juga terlihat pada aplikasi cuka kayu dengan konsentrasi $10 \mathrm{ml} \mathrm{I}^{-1}$. Aplikasi cuka kayu dengan konsentrasi $5 \mathrm{ml} \mathrm{l}^{-1}, 20 \mathrm{ml} \mathrm{l}^{-1}, 40 \mathrm{ml} \mathrm{l}^{-1}$ dan $80 \mathrm{ml} \mathrm{l}^{-1}$ menunjukkan lama stadia pupa lebih singkat yaitu delapan hari hingga terbentuk imago. Setelah mengalami pembentukan stadia pupa, berlanjut ke proses hidup selanjutnya yaitu imago. Lama stadia imago pada kontrol yaitu sembilan hari. Pada perlakuan yang lain, lama stadia imago bisa mencapai 12-14 hari.
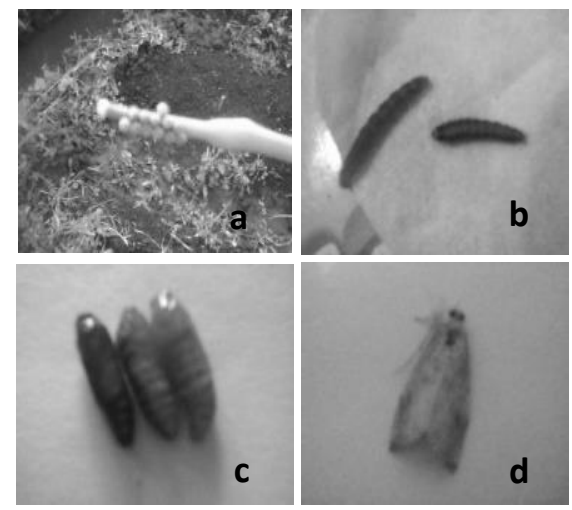

Gambar 3. Biologi Crocidolomia pavonana (a) telur, (b) larva, (c) pupa, dan (d) imago 


\section{Efektifitas Cuka Kayu terhadap Kemampuan Makan C. pavonana}

Berdasarkan hasil penelitian menunjukkan bahwa pemberian perlakuan cuka kayu dapat berpengaruh secara nyata terhadap kemampuan makan. Pada tabel 5 dapat dilihat bahwa perlakuan tanpa cuka kayu (kontrol) berbeda nyata dengan perlakuan cuka kayu berbagai konsentrasi (konsentrasi $5 \mathrm{ml} \mathrm{I}^{-1}, 10 \mathrm{ml}$ $\mathrm{I}^{-1}, 20 \mathrm{ml} \mathrm{l}^{-1}, 40 \mathrm{ml} \mathrm{I}^{-1}$, dan $80 \mathrm{ml} \mathrm{I}^{-1}$ ).

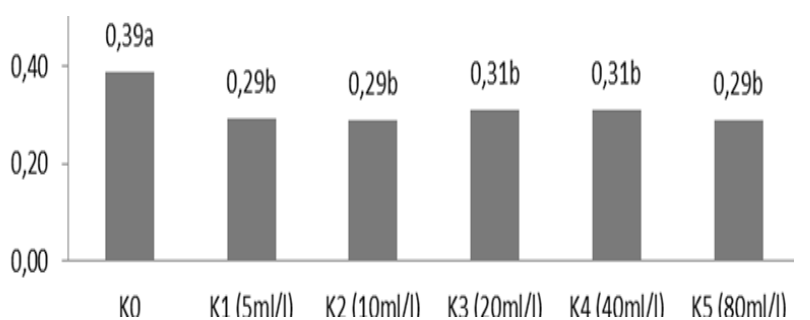

Keterangan: Angka-angka pada tiap kolom yang diikuti huruf yang sama tidak berbeda nyata pada DMRT taraf $5 \%$

Gambar 3. Efektifitas cuka kayu terhadap kemampuan makan C. pavonana

\section{Efektifitas Cuka Kayu terhadap Intesitas Serangan Hama}

Hasil pengamatan menunjukkan bahwa pengaplikasian cuka kayu terhadap tanaman sawi menunjukkan pengaruh yang nyata terhadap intensitas serangan larva $C$. pavonana.

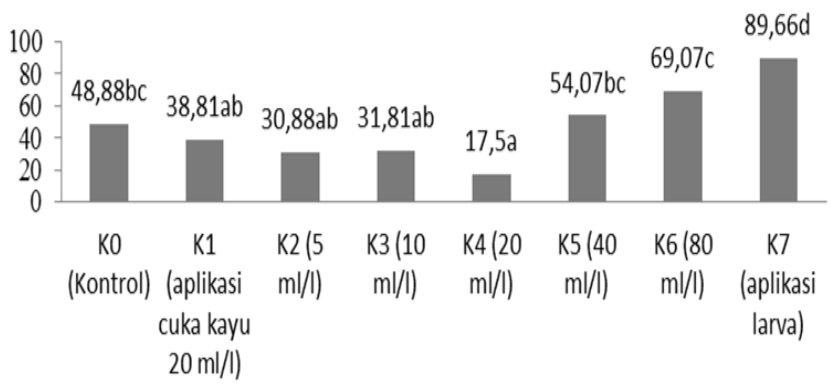

Keterangan: Angka-angka pada tiap kolom yang diikuti huruf yag sama tidak berbeda nyata pada DMRT taraf $5 \%$

Gambar 4. Efektifitas cuka kayu terhadap kemampuan makan C. Pavonana
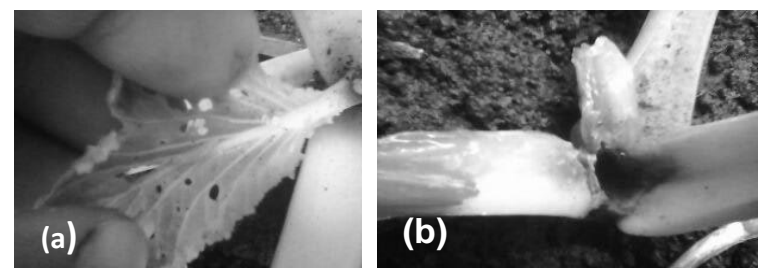

Gambar 5. Intensitas serangan larva $C$. pavonana (a) Serangan pada daun muda. (b) Serangan pada pangkal batang daun

\section{Efektifitas Cuka Kayu terhadap Tinggi Tanaman Sawi}

Hasil pengamatan menunjukkan bahwa pengaplikasian cuka kayu memiliki pengaruh yang tidak nyata terhadap tinggi tanaman sawi. Diantara konsentrasi cuka kayu yang telah diaplikasikan, konsentrasi yang paing baik bagi pertumbuhan tingi tanaman sawi yaitu konsentrasi $20 \mathrm{ml} \mathrm{I}^{-1}$ yang terbukt pada hasil pengamatan terakhir.

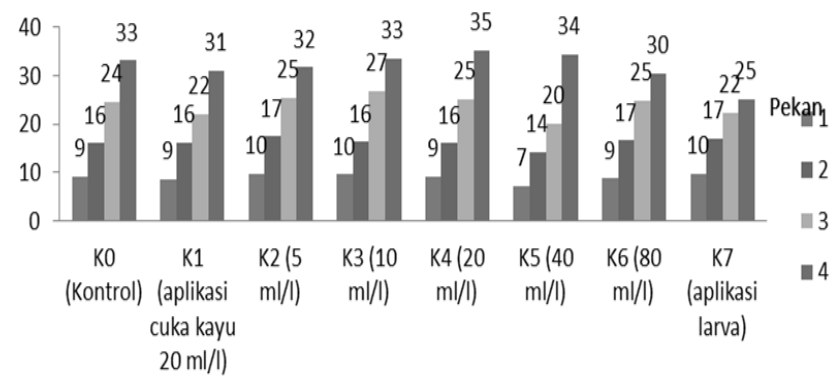

Gambar 5. Efektifitas cuka kayu terhadap tinggi tanaman sawi

Semakin besar perlakuan konsentrasi yang diberikan pada tanaman sawi tidak terlihat memberikan hasil yang nyata terhadap pertambahan tinggi tanaman sawi. Hanya saja, cuka kayu yang diindikasikan berfungsi sebagai hormon atau enzim, dapat memacu suatu proses reaksi yang perananya seperti horman. Proses perbaikan lahan semakin cepat, sehingga nutrisi tanah bisa diserap lebih banyak. Penyerapan nutrisi yang lebih cepat menyebabkan tanaman mudah untuk tumbuh besar dan tinggi.

\section{Efektifitas Cuka Kayu terhadap Jumlah Daun Tanaman Sawi}

Hasil pengamatan menunjukkan bahwa pengaplikasian cuka kayu memilki pengaruh yang tidak nyata terhadap jumlah daun tanaman sawi. Pada hasil pengamatan tersebut diketahui semakin besar perlakuan konsentrasi cuka kayu yang diberikan lebih memberikan sumbangan terbesar juga terhadap jumlah daun tanaman sawi.

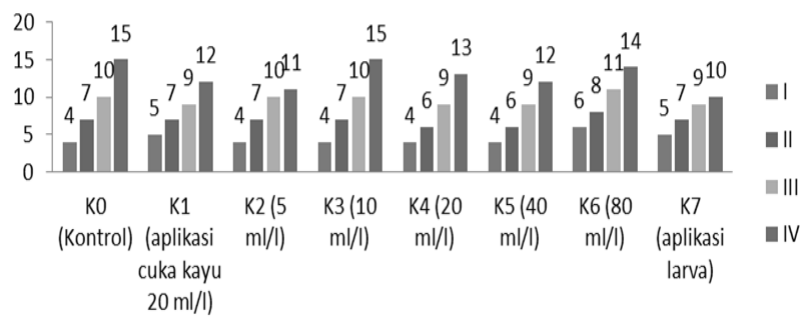

Gambar 6. Efektifitas cuka kayu terhadap jumlah daun pada tanaman sawi

\section{Efektifitas Cuka Kayu terhadap Berat Tanaman Sawi}

Hasil pengamatan menunjukkan bahwa pengaplikasian cuka kayu memilki pengaruh yang tidak nyata terhadap berat daun tanaman sawi. Pada gambar 10 terlihat rata- rata berat daun pada tiap perlakuan. Rata- rata berat daun terbesar terdapat 
pada perlakuan konsentrasi cuka kayu $20 \mathrm{ml} \mathrm{l}^{-1}$ (K4) yaitu sebesar 128,93 gram. Rata- rata berat daun yang paling kecil yaitu pada tanpa perlakuan cuka kayu (K7) yaitu sebesar 18,3 gram.

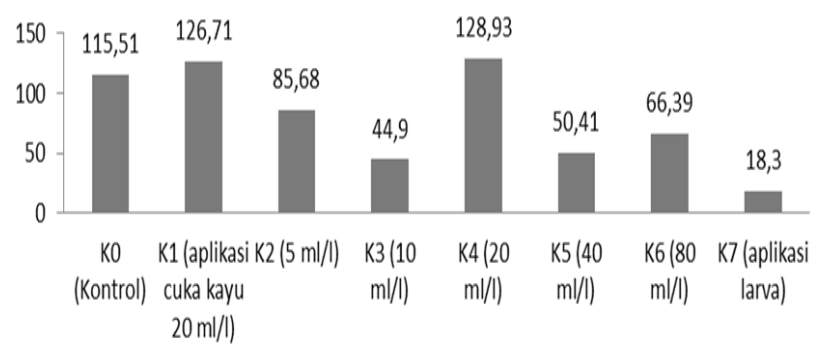

Gambar 7. Efektifitas cuka kayu terhadap jumlah daun pada tanaman sawi

\section{KESIMPULAN DAN SARAN}

\section{Kesimpulan}

Berdasarkan hasil penelitian yang dilakukan, dapat disimpulkan bahwa:

1. Cuka kayu tidak efektif sebagai pestisida nabati dalam pengendalian hama $C$. pavonana pada sawi. Cuka kayu dapat membantu mempercepat siklus hidup $C$. pavonana.

2. Cuka kayu dapat membantu mempertinggi dan memperbanyak daun tanaman sawi sehingga bisa dikatakan efektif sebagai zat perangsang tumbuh tanaman sawi. Semakin besar konsentrasi cuka kayu yang diberikan, pertumbuhannya bertambah (baik tinggi maupun jumlah daun tanaman sawi).

\section{Saran}

yaitu:

Saran yang dapat diberikan dari penelitian ini

1. Cuka kayu sangat efektif dalam upaya membantu mempercepat proses rearing hama $C$. pavonana untuk kebutuhan penelitian atau perbanyakan $C$. pavonana sebagai pakan ternak.

2. Perlu melakukan pengamatan mengenai mortalitas dan siklus hidup $C$. pavonana di lapangan setelah aplikasi cuka kayu untuk penelitian selanjutnya.

\section{DAFTAR PUSTAKA}

Anonim. 2003. Pestisida nabati untuk hama tanaman sawi. Lembar Informasi Pertanian BPTP Jakarta. No./02/IPL/LIPTAN/BPTP JKT/2003.

Anonim. 2012. Cuka kayu dari limbah industri arang. Forum Kerjasama Agribisnis.

Balfas R, Sutopo. 1998. Laporan hasil pengujian destilat kayu jati, tusam, bakau dan karet terhadap ulat pemakan daun wungu dan kumbang moncong lada. Balai Penelitian Tanaman Rempah dan Obat. Bogor.

Girrard JP. 1992. Technology of meat and meat products. New York (NY): Ellis Horwood.

Sudarwohadi S, Wiwin S. 1993. Hama-hama tanaman kubis dan cara pengendaliannya, hal 39-50. Dalam Permadi, A.H. dan Sastrosiswojo (Eds). Kubis. Kerjasama Badan Litbang Pertanian Balai Penelitian Hortikultura Lembang dengan Program Nasional PHT Bappenas.

Sudarmo, Subiyakto. 1991. Pengendalian serangga hama sayuran dan palawija. Yogyakarta (ID): Kanisius. 